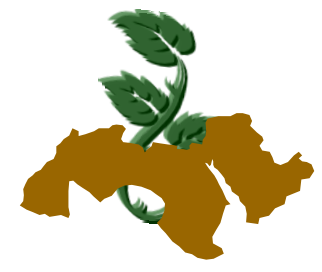

Arab Univ.

J. Agric. Sci., Ain Shams Univ., Cairo, 21(1), 79-89, 2013

\title{
AUTECOLOGY AND BIOLOGY OF HANDAL (Citrullus coloynthsis L.) DESERT PLANT
}

\author{
Osman E. Mohammed ${ }^{1}$ and Abdel Rahman A. El-Mahdi ${ }^{1}$ \\ 1- Department of Crop Production, Faculty of Agriculture, Nile Valley University, Sudan
}

Keywords: Citrullus, Coloynthsis, autecology, biology

\begin{abstract}
The present study was carried out in the desert valley (wadi) Abu Salam (63 Km.) east of Berber city, River Nile State, and in the nursery of the Faculty of Agriculture, Nile Valley University. The autecology and biology of major desert specie, Handal (Citrullus coloynthsis), were studied. The study area (Wadi Abu Salam) was divided into three sections; upper, middle and lower. The soil was classified as sodic soil and contained a high percentage of clay in the upper section, equal percentage of clay and sand in the middle section and high percentage of sand in the lower section. The distribution of Handal plant in the wadi area was investigated. In the first season, it was only detected in the middle section $\left(0.60-0.72\right.$ plants $\left./ \mathrm{m}^{2}\right)$. In the second season, the plant was distributed in the three sections of the wadi (1.46-1.66 plants/m2 for the upper section, $0.27-0.49$ plants $/ \mathrm{m} 2$ for the middle section and 0.3-0.4 plants $/ \mathrm{m}^{2}$ for the lower sections). The rate of photosynthesis increased during the first stage of growth to reach its maximum (2.2$2.34 \mathrm{gm} /$ day) during the $8^{\text {th }}$ week from the start of germination, then started to decline till it reached its minimum rate $(0.10-0.12 \mathrm{gm} /$ day) at the maturity stage in both seasons. Plant roots growth started at a low rate, then, increased with plant development and became equal after 7 weeks from germination. After that, it decreased until it reached its lowest rate at the stage of maturity.
\end{abstract}

INTRODUCTION

The ecology of wadi Abu Salam was studied as a representative of the many similar wadies in the Northern Region of Sudan. Running through the Nubian desert, the wadi receives irregular low rainfall. The soils of the wadi are generally classified as alkaline, formed in situ by colluviums and alluvium and are mainly affected by wind erosion due to the low flora cover (Mohamed, 1989). CloudilyThompson (1965) reported that, this type of desert sand dune usually occurs where sand is relatively scarce and the wind direction is constant. Different groups of nomads, semi-nomads and seasonal cultivators use the wadi. Herbs and grasses, which compose $75 \%$ of wadi Abu Salam vegetation, are frequently palatable and highly nutritive and believed to support the indigenous animal population for a considerable part of the year. However, the main sources of income for the local habitats are the sale of livestock and/or limited agricultural crops (Mohamed, 1989).

The vegetation cover of the wadi is seriously reduced due to overgrazing, over cultivation and prolonged drought which led to soil erosion and sand encroachment over different places.

Handal (Citrullus coloynthsis) is known to grow widely in warm deserts and hot places in North Africa and the Arabian deserts. It spreads in most of the Arab countries among which is the Sudan. It also grows a long the sea coasts of Northern Africa, Southern Europe and Western Asia (EI Awodat and Laham, 1992 and EL Adjoy, 1996). Handal commonly occurred in pastures cultivated and fallow fields.

It is common practice in Sudan to feed animals on fallow fields, edge of cultivation as well as pastures were Hanadl is at hand (Al Awad, 1981). The leaves and stems of the plant are eaten by goats and dissert animals while the fruits are eaten by donkeys.

Some west tropical African tribes eat the cooked seeds of Handal (Al/Allah, 1997 and Dalziol, 1937). The oil extracted from the seeds (by pressing) is also used for massage and seeds residues are roasted like coffee beans and eaten as bread (A.A.A.D., 1988 and EL-Djoy, 1996). Further, Handal is used as a remedy for many diseas- 
es such as rheumatism, malaria, stomach complaint, stitching of injuries and as purgative. As Handal plant autecology's and biology are not much known, the investigation of its biology becomes important to lay a foundation for their preservation as part of Sudan's efforts to study and preserve its biodiversity. Therefore, the objectives of this study are to describe, analyze and understand mechanisms of Handal plant distribution in relation to soil characteristics.

\section{MATERIALS AND METHODS}

The experiment was carried out during the two successive seasons of 2004/2005 and 2005/2006 on Wadi Abu Salam (dessert valley), Berber Locality, River Nile State, Northern Sudan (Latitude $17^{\circ}$ $22^{\prime \prime} \mathrm{N}$, Longitudes $36^{\circ} 25^{\prime \prime} \mathrm{E}$ ).

Wadi Abu Salam (Fig. 1) is geographically divided into eleven parts according to its ecological similarity using GPS (GARMIN, GPS, 12 XL. Personal Navigator, (1998) GARMIN Corporation (Table 1). For the purpose of this study, Wadi Abu salam was divided into three equally major sections; upper, middle and lower. The area of each section is about $21 \mathrm{sq}$. $\mathrm{Km}$. The upper section covers the area from Jebal Abu Salam to Umm Rueit and composed of four parts, the middle section which composes four parts extended from EL Kubsit to Umm Simera and the lower section included three parts and extended through Umm Sarih, Dabal, and EL ku.

\section{Data collection}

The data collected included the followings:

\section{Field distribution in relation to soil characteris-} tics

Sampling points were randomly selected in the upper, middle and lower sections of the wadi to study plants density and major soil conditions.

Source: Survey Department - Khartoum (2004) (sheet No. 45G)

\section{Soil sampling and analysis}

Eight soil samples were collected randomly from each sampling transects at two depths (layers): $0-30$ and $30-60 \mathrm{~cm}$. One $\mathrm{kg}$ of a composite sample was extracted from each layer from each of the eleven parts. Soil physical and chemical characteristics were analyzed at the Soil and Chemistry Department, Hudeiba Research Station, Sudan. Standard analytical methods ( as described by Ryan et al 2001) were used to determine sand, clay, and loamy soil, $\mathrm{pH}$, saturation percentage $(\mathrm{SP})$, electric conductivity (EC), soluble cations and anions, sodium adsorption ratio (SAR) and exchangeable sodium percent (ESP).

\section{Soil moisture}

Wet soil samples were randomly collected from each sampling transect at two depths; 0-30 and 30-60 cm, parallel to the density sampling. Samples were dried in an oven at $105^{\circ} \mathrm{C}$ for 24 hours to obtain moisture content.

\section{Plant density}

Plant density was computed by counting the individual plants, which were then related to the area of the transect (plants $/ \mathrm{m}^{2}$ ) through stages of plant growth. (emergence, first 2- 4 leaves, first flowering, first fruits setting and second flowering, first seeds formation and second fruits setting, second seeds formation).

\section{Physiological attributes}

This experiment was conducted in the nursery of Faculty of Agriculture, Nile Valley University. It aims to study regularly, at 2 weeks interval, the followings:

\section{The rate of photosynthesis}

The rate of photosynthesis of each plant was calculated by the Net Assimilation Rate equation (NAR) according to Watson (1985)

$$
N A R=\frac{w i-w i-1}{T i-T i-1} \times \frac{2.3 \log A i-2.3 \log A i-1}{A i-A i-1}
$$

Were:

w: dry weight of plants $(\mathrm{g})$.

A: leaves surface area.

$\mathrm{T}$ : time (weeks).

I: Time of sample (day).

2.3 log: Naberian logarithm.

Four samples were taken to calculate leaf area by Area-meter (LI-COR/inc. Lincoln, Nebraska, USA. Model 3100). The dry weight of samples was estimated using an oven at $80^{\circ} \mathrm{C}$ for 24 hours. 


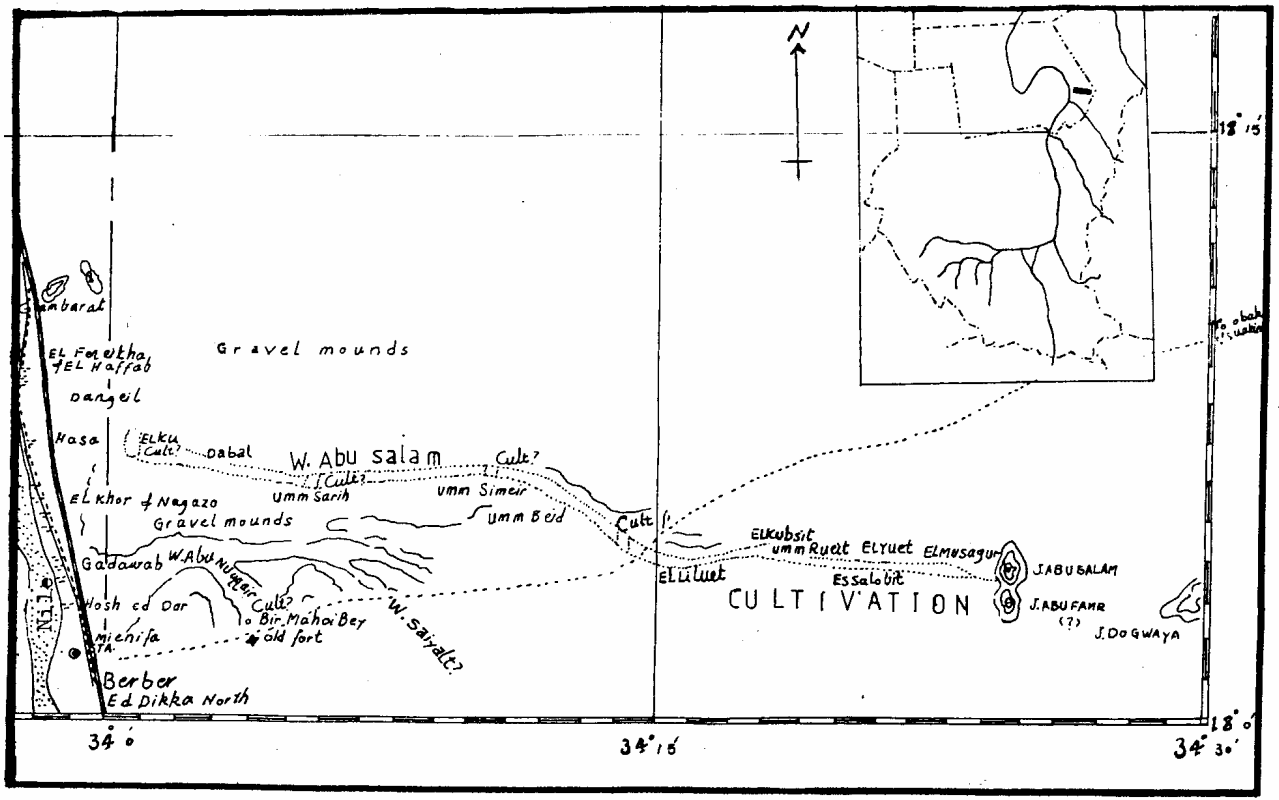

Fig. 1. Locality Map of Wadi Abu Salam - Nile Province

Table 1. The Wadi Abu Salam Sections, Name, GPS and Distance from Nile Bank

\begin{tabular}{|c|c|c|c|c|}
\hline \multirow{5}{*}{ Upper } & No & Sites Name & GPS & D. From Nile bank /km \\
\hline & 1 & EL Musgur & $\begin{array}{c}\text { N 18,00', 103" } \\
\text { E } 34,28,659^{\prime \prime}\end{array}$ & 63.60 \\
\hline & 2 & EL Yuet & $\begin{array}{l}\text { N 18,03', 410" } \\
\text { E 34,19', 637" }\end{array}$ & 54.70 \\
\hline & 3 & ELSalobit & $\begin{array}{l}\text { N 18,20', 718" } \\
\text { E 34,19', 625" }\end{array}$ & 51.70 \\
\hline & 4 & Umm Rueit & $\begin{array}{l}\text { N 18,20', 718" } \\
\text { E 34,19', 626" }\end{array}$ & 47.50 \\
\hline \multirow{4}{*}{ Middle } & 5 & EL Kubsit & $\begin{array}{l}\text { N 18,01', 680" } \\
\text { E 34,17', 694" }\end{array}$ & 42.80 \\
\hline & 6 & EL Lilueit & $\begin{array}{l}\text { N 18,03', 042" } \\
\text { E 34,16', 006" }\end{array}$ & 37.20 \\
\hline & 7 & Umm Beid & $\begin{array}{l}\text { N 18,02', 962" } \\
\text { E 34,13', 223" }\end{array}$ & 33.60 \\
\hline & 8 & Umm Simeira & $\begin{array}{l}\text { N 18,50', 800" } \\
\text { E 34,11', 906" }\end{array}$ & 28.50 \\
\hline \multirow{3}{*}{ Lower } & 9 & Umm Sarih & $\begin{array}{l}\text { N 18,06', 176" } \\
\text { E 34,08', 902" }\end{array}$ & 22.70 \\
\hline & 10 & Dabal & $\begin{array}{l}\text { N 18,06', 457" } \\
\text { E 34,05', 364" }\end{array}$ & 20.70 \\
\hline & 11 & EL Ku & $\begin{array}{l}\text { N 18,07', 738" } \\
\text { E 34,04', 272" }\end{array}$ & 18.20 \\
\hline
\end{tabular}




\section{Shoot /root ratio}

Four samples were taken fortnightly, to calculate shoot/root ratio.

\section{Statistical analysis}

Data were subjected to probability analysis (MSTAT- C program, 1991) and Duncan's Multiple Range Test.

\section{RESULTS AND DISCUSSION}

\section{Soil physical characteristics}

The physical analysis of the soil of the $3 \mathrm{sec}$ tions of the wadi is presented in Table (2). In the upper section, the top layer $(0-30 \mathrm{~cm}$. depth) soil constituted $51-57 \%$ clay, $40.5-43 \%$ sand and $2.2-$ $6 \%$ silt. The bottom layer $(30-60 \mathrm{~cm}$. depth) constituted $50-63 \%$ clay $36.6-45 \%$ sand and $2.9-9.4 \%$ silt. The soil of this section can be described as clay and sandy at both depths. In the middle section, the top layer of the soil constituted $32.6-51 \%$ clay, $40.8-65 \%$ sand and $2.4-10.4 \%$ silt, and the bottom layer constituted $36.6-56 \%$ clay, $44-60 \%$ sand and $3.0-9.0 \%$ silt. So, the soil of this section can be described as clay- sand- silt soil. In the lower section of the wadi, the top layer of the soil composed of $71-74.6 \%$ sand, $25-31 \%$ clay and $0.3-2.7 \%$ silt and the bottom layer is composed of $60.4-64.2 \%$ sand, $34.8-36.2 \%$ clay and $0.4-5.6 \%$ silt. The soil of this section of the wadi can be described as sandy-clay soil.

Results showed that, the percentage of clay in the soil decreases and the sand increases as we go closer to River Nile banks. In the middle section; however; both constituent's clay and sand were nearly equal. The soil texture of the lower section can be described as sandy clay loam, that of the middle section as sandy clay and of the upper section as clay. These results are in agreement with the findings of Mohamed (1989). He explained the presence of sandy layers of the soil to be due to deposition of depressions by East-North and North winds.

\section{Soil chemical characteristics}

The chemical characteristics of the soils of the three sections of the wadi are illustrated in (Table 3). The soil of the wadi can be described as non saline and non-sodic. It is mainly alkaline $(\mathrm{PH} 8.1$ 8.7). The electric conductivity (EC) was measured as $0.26-0.90 \mathrm{~mm} . / \mathrm{hour} / \mathrm{cm}$. in the top layer and $0.33-1.0 \mathrm{~mm} . / \mathrm{hour} / \mathrm{cm}$. in the bottom layer, at
$25 \mathrm{C}$. The exchangeable sodium percentage (ESP) was $0.06-10.01 \%$ in the top layer and 0.06 $12.32 \%$ in the bottom layer. However, these results also agree with the findings of Mohammed (1989). The high soil alkalinity and the good soil properties of wadi Abu Salam could be attributed to the presence of carbonate and bi-carbonate ions and the gentle slope of the wadi $(0.03 \mathrm{~m} / \mathrm{km})$ which enhanced precipitation of fertile soil. Excess soil salts is also leached by annual run-off.

\section{Soil moisture}

The results of soil moisture content of Wadi Abu Salam during the two seasons are shown in Table (4). In the first season, very low moisture content was recognized in both upper and lower sections of the wadi, while higher levels of moisture were recorded in the middle section (10.9$38.33 \%$ and $8.56-26.46 \%$ for the top and bottom layers, respectively). This could be attributed to the seasonal rainfall confined to the middle section. In this region of the country, the seasonal rainfall sometimes does not cover the whole area

However, in the second season, the higher levels of moisture content recorded for the three sections of the research site which could be related to the rainfall that covered the whole area of the wadi in that season. The highest soil moisture content $(44 \%)$ was detected at the bottom layer of the lower section, while the lowest moisture content (8.27 $\%$ ) was observed at the top layer of the middle section.

\section{Distribution of Handal}

The distribution of Handal plant in wadi Abu Salam area at different growth stages is illustrated in Fig. (2a and 2b). In the first season, while Handal growth was noticed in the middle section, there was no evidence of its growth in the upper and lower sections of the wadi. This could be attributed to lack of rainfall in the upper and lower section. While in the second season, where the whole wadi area was covered by rain showers, Handal plants grow eventually in all sections of the wadi. That confirms the liability of this plant to grow in a wide range of soil composition (sand- clay soils).

\section{Density of Handal}

The density of Handal plant (Plants $/ \mathrm{m}^{2}$ ) in the research site during the two seasons is illustrated in Fig. $3 a$ and $3 b$ at different growth stages. The plant density was calculated from emergence to 
Table 2. Soil Physical Characteristic of Wadi Abu Salam

\begin{tabular}{|c|c|c|c|c|c|c|}
\hline $\begin{array}{l}\text { Section } \\
\text { of Wadi }\end{array}$ & Site & $\begin{array}{l}\text { Distance } \\
\text { from Nile } \\
(\mathrm{Km} .)\end{array}$ & $\begin{array}{c}\text { Depth } \\
\mathrm{Cm} .\end{array}$ & Sand \% & Clay \% & $\begin{array}{c}\text { Silt } \\
\%\end{array}$ \\
\hline \multirow{8}{*}{ Upper } & \multirow{2}{*}{1} & \multirow{2}{*}{60.6} & $0-30$ & 42.8 & 55.0 & 2.2 \\
\hline & & & $30-60$ & 44.0 & 53.1 & 2.9 \\
\hline & \multirow{2}{*}{2} & \multirow{2}{*}{51.7} & $0-30$ & 42.8 & 51.2 & 6.0 \\
\hline & & & $30-60$ & 36.6 & 63.0 & 9.4 \\
\hline & \multirow{2}{*}{3} & \multirow{2}{*}{48.7} & $0-30$ & 43.0 & 54.4 & 2.6 \\
\hline & & & $30-60$ & 39.8 & 54.6 & 5.6 \\
\hline & \multirow{2}{*}{4} & \multirow{2}{*}{44.5} & $0-30$ & 40.5 & 57.2 & 2.3 \\
\hline & & & $30-60$ & 45.0 & 50.0 & 5.0 \\
\hline \multirow{8}{*}{ Middle } & \multirow{2}{*}{5} & \multirow{2}{*}{39.8} & $0-30$ & 47.6 & 44.4 & 8.0 \\
\hline & & & $30-60$ & 41.0 & 56.0 & 3.0 \\
\hline & \multirow{2}{*}{6} & \multirow{2}{*}{34.2} & $0-30$ & 40.8 & 51.0 & 8.2 \\
\hline & & & $30-60$ & 44.0 & 46.8 & 9.2 \\
\hline & \multirow{2}{*}{7} & \multirow{2}{*}{30.6} & $0-30$ & 65.0 & 32.6 & 2.4 \\
\hline & & & $30-60$ & 60.0 & 36.6 & 3.4 \\
\hline & \multirow{2}{*}{8} & \multirow{2}{*}{25.5} & $0-30$ & 49.6 & 40.0 & 10.4 \\
\hline & & & $30-60$ & 44.8 & 51.2 & 04.0 \\
\hline \multirow{6}{*}{ Lower } & \multirow{2}{*}{9} & \multirow{2}{*}{19.7} & $0-30$ & 71.0 & 27.0 & 2.0 \\
\hline & & & $30-60$ & 60.4 & 34.8 & 5.6 \\
\hline & \multirow{2}{*}{10} & \multirow{2}{*}{17.7} & $0-30$ & 66.2 & 31.1 & 2.7 \\
\hline & & & $30-60$ & 61.0 & 36.2 & 2.8 \\
\hline & \multirow{2}{*}{11} & \multirow{2}{*}{16.2} & $0-30$ & 74.6 & 25.1 & 0.3 \\
\hline & & & $30-60$ & 64.2 & 35.4 & 0.4 \\
\hline
\end{tabular}

Table 3. Chemical Analysis of Wadi Abu Salam Soi

\begin{tabular}{|c|c|c|c|c|c|c|c|c|c|c|}
\hline $\begin{array}{l}\text { Section } \\
\text { of Wadi }\end{array}$ & $\begin{array}{l}\text { Site } \\
\text { No }\end{array}$ & $\begin{array}{c}\text { Dep / } \\
\text { cm. }\end{array}$ & S.P.* & PH & $\begin{array}{l}\mathrm{EC}^{\star \star} \\
\mathrm{mm} . / \\
\mathrm{cm} .\end{array}$ & $\begin{array}{c}\mathrm{Na} \\
\mathrm{Meq} /\end{array}$ & $\begin{array}{l}\mathrm{Ca}+\mathrm{Mg} \\
\mathrm{Meq} / \mathrm{L}\end{array}$ & $\begin{array}{c}\mathrm{Co}+\mathrm{Hco} \\
\mathrm{Meq} / \mathrm{L}\end{array}$ & $\mathrm{SAR}^{\star \star \star}$ & ESP $P^{\star \star \star *}$ \\
\hline \multirow{8}{*}{ Upper } & \multirow{2}{*}{1} & $00-30$ & 34.0 & 8.10 & 0.71 & 0.65 & 2.40 & 2.00 & 1.00 & 0.79 \\
\hline & & $30-60$ & 45.0 & 8.30 & 0.74 & 5.00 & 0.60 & 2.00 & 9.00 & 10.88 \\
\hline & \multirow{2}{*}{2} & $00-30$ & 53.0 & 8.4 & 0.53 & 1.52 & 7.00 & 7.00 & 1.00 & 0.60 \\
\hline & & $30-60$ & 53.0 & 8.5 & 0.85 & 4.34 & 1.00 & 4.00 & 5.00 & 5.55 \\
\hline & \multirow{2}{*}{3} & $00-30$ & 47.0 & 8.5 & 0.46 & 3.40 & 2.60 & 3.00 & 3.00 & 3.00 \\
\hline & & $30-60$ & 43.0 & 8.6 & 0.42 & 6.30 & 2.40 & 3.00 & 6.00 & 6.73 \\
\hline & \multirow{2}{*}{4} & $00-30$ & 48.0 & 8.5 & 0.26 & 2.40 & 1.20 & 4.00 & 3.00 & 3.20 \\
\hline & & $30-60$ & 35.0 & 8.5 & 0.34 & 4.34 & 2.80 & 4.00 & 4.00 & 4.00 \\
\hline \multirow{8}{*}{ Middle } & \multirow{2}{*}{5} & $00-30$ & 40.0 & 8.6 & 0.36 & 4.80 & 1.20 & 4.00 & 6.00 & 7.30 \\
\hline & & $30-60$ & 48.0 & 8.6 & 0.33 & 5.90 & 0.80 & 4.00 & 9.00 & 11.11 \\
\hline & \multirow{2}{*}{6} & $00-30$ & 45.0 & 8.7 & 0.35 & 2.60 & 0.40 & 4.00 & 6.00 & 6.82 \\
\hline & & $30-60$ & 43.0 & 8.3 & 0.50 & 3.04 & 1.00 & 3.00 & 4.00 & 4.84 \\
\hline & \multirow{2}{*}{7} & $00-30$ & 30.0 & 8.7 & 0.60 & 4.60 & 1.60 & 3.00 & 5.00 & 5.95 \\
\hline & & $30-60$ & 30.0 & 8.6 & 0.65 & 5.44 & 1.40 & 3.00 & 7.00 & 7.69 \\
\hline & \multirow{2}{*}{8} & $00-30$ & 37.0 & 8.5 & 0.70 & 3.26 & 2.00 & 3.00 & 3.00 & 3.43 \\
\hline & & $30-60$ & 33.0 & 8.7 & 1.00 & 4.80 & 0.40 & 3.00 & 11.00 & 12.12 \\
\hline \multirow{6}{*}{ Lower } & \multirow{2}{*}{9} & $00-30$ & 28.0 & 8.5 & 0.90 & 1.72 & 1.40 & 2.00 & 2.00 & 1.78 \\
\hline & & $30-60$ & 28.0 & 8.6 & 0.85 & 1.95 & 0.40 & 3.00 & 4.00 & 4.92 \\
\hline & \multirow{2}{*}{10} & $00-30$ & 23.0 & 8.4 & 0.70 & 4.60 & 0.60 & 3.00 & 8.00 & 10.01 \\
\hline & & $30-60$ & 25.0 & 8.4 & 0.64 & 10.65 & 1.00 & 3.00 & 15.0 & 12.32 \\
\hline & \multirow{2}{*}{11} & $00-30$ & 28.0 & 8.5 & 0.91 & 1.10 & 3.20 & 2.00 & 1.00 & 0.06 \\
\hline & & $30-60$ & 25.0 & 8.2 & 0.65 & 1.10 & 3.00 & 1.00 & 1.00 & 0.06 \\
\hline
\end{tabular}

${ }^{*} \mathrm{~S} . \mathrm{P}=$ Saturation Percentage ${ }^{* *} \mathrm{SAR}=$ Sodium Adsorption Ratio
${ }^{* *} \mathrm{Ec}=$ Electrical Conductivity

${ }^{* * *}$ ESP $=$ Exchangeable Sodium Percentage 
Table 4. Soil Moisture Content of Wadi Abu Salam During Seasons 2004/05 and 2005/06 Compared with Plant Growth Stages

\begin{tabular}{|c|c|c|c|c|c|c|c|c|c|c|c|c|}
\hline \multirow[b]{2}{*}{ Section of Wadi } & \multicolumn{6}{|c|}{ Season $2004 / 05$} & \multicolumn{6}{|c|}{ Season 2005 / 06} \\
\hline & \multicolumn{2}{|c|}{ Upper } & \multicolumn{2}{|c|}{ Middle } & \multicolumn{2}{|c|}{ Lower } & \multicolumn{2}{|c|}{ Upper } & \multicolumn{2}{|c|}{ Middle } & \multicolumn{2}{|c|}{ Lower } \\
\hline Stage of plant & $0-30$ & $30-60$ & $0-30$ & $30-60$ & $0-30$ & $30-60$ & $0-30$ & $30-60$ & $0-30$ & $30-60$ & $0-30$ & $30-60$ \\
\hline Emergence & 0.0 & 0.0 & 26.5 & 38.7 & 0.0 & 0.0 & 31.3 & 38.0 & 34.0 & 41.5 & 37.0 & 44.0 \\
\hline First 2- 4 Leaves & 0.0 & 0.0 & 20.6 & 32.6 & 0.0 & 0.0 & 23.0 & 33.2 & 26.2 & 36.1 & 25.0 & 39.5 \\
\hline First Flowering & 0.0 & 0.0 & 17.7 & 27.8 & 0.0 & 0.0 & 15.8 & 28.2 & 19.1 & 27.3 & 18.5 & 24.4 \\
\hline $\begin{array}{l}\text { First Fruits Setting } \\
\text { and } 2^{\text {nd }} \text { Flowering } \\
\text { First Seeds }\end{array}$ & 0.0 & 0.0 & 13.9 & 21.2 & 0.0 & 0.0 & 14.1 & 25.3 & 16.5 & 25.0 & 14.5 & 22.0 \\
\hline $\begin{array}{c}\text { Formation } \\
\text { and } 2^{\text {nd }} \text { Setting }\end{array}$ & 0.0 & 0.0 & 10.9 & 16.0 & 0.0 & 0.0 & 12.0 & 18.8 & 10.2 & 22.0 & 11.5 & 18.7 \\
\hline $2^{\text {nd }}$ Seeds Formation & 0.0 & 0.0 & 08.6 & 10.9 & 0.0 & 0.0 & 10.1 & 17.9 & 08.3 & 17.3 & 09.9 & 16.4 \\
\hline
\end{tabular}

(a)

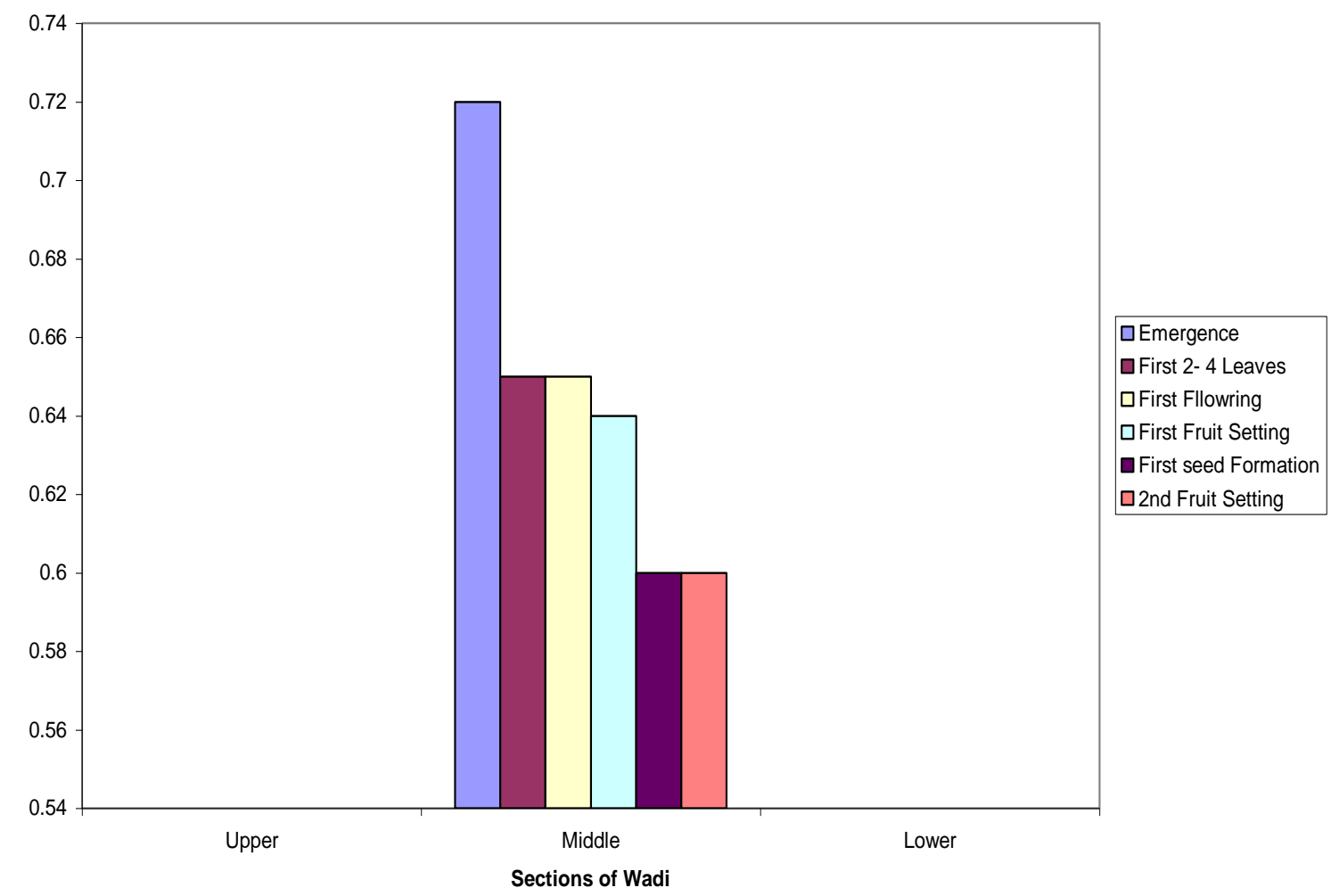

Arab Univ. J. Agric. Sci., 21(1), 2013 
(b)

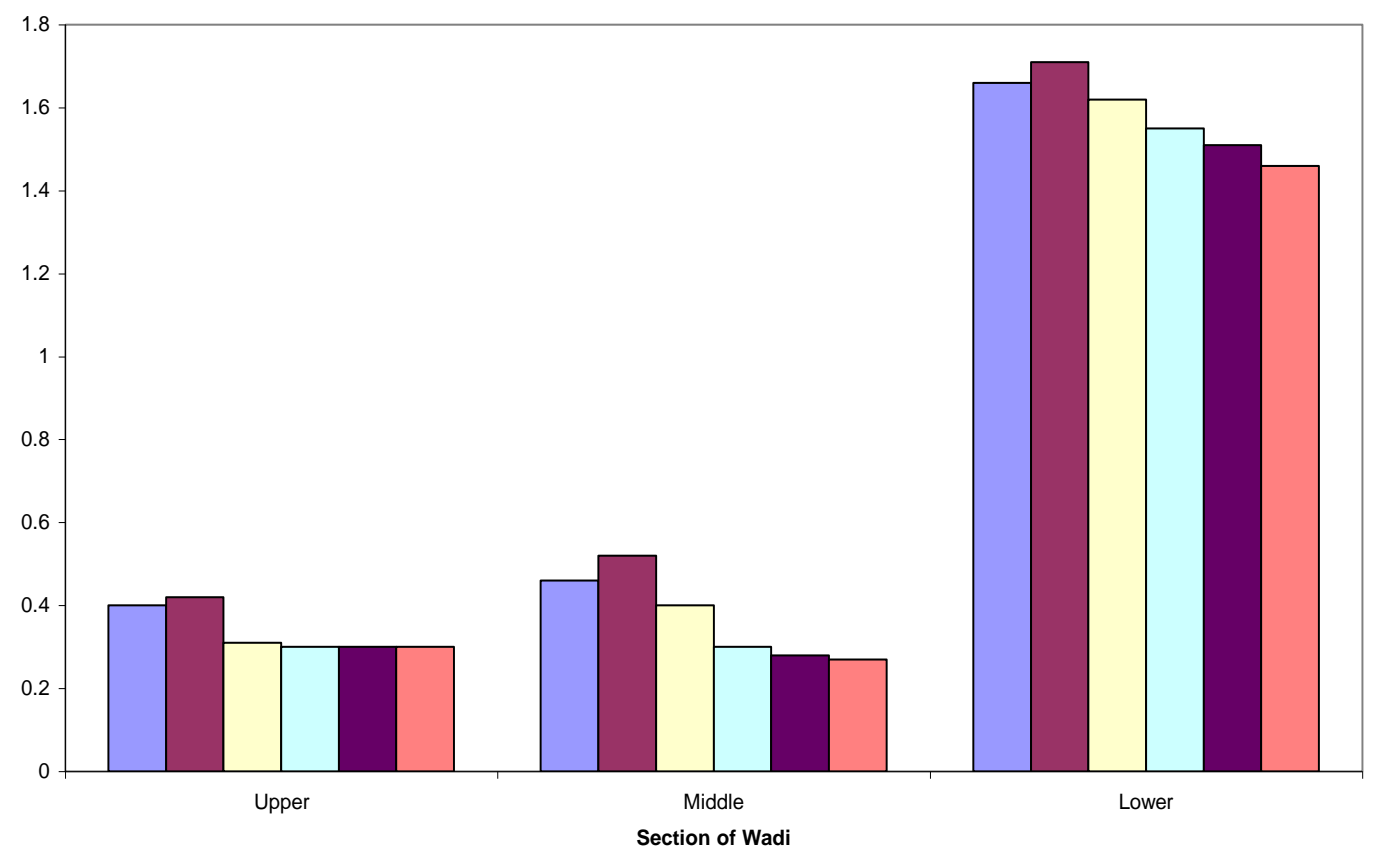

Fig. 2. Distribution of Handal plant in Wadi Abu Salam (a) Season 2004 / 2005 (b) Season 2005/2006

(a)

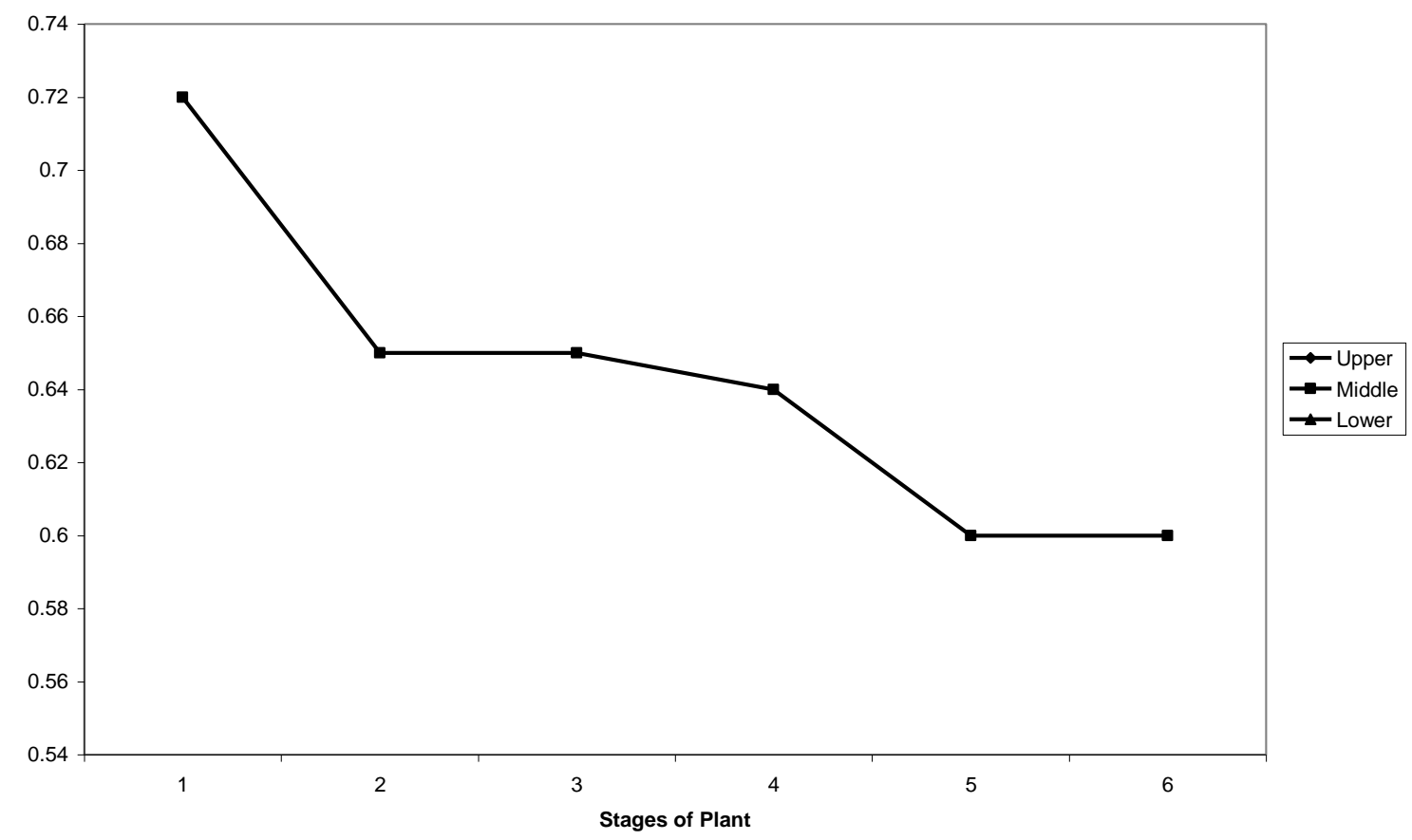

Arab Univ. J. Agric. Sci., 21(1), 2013 
(b)

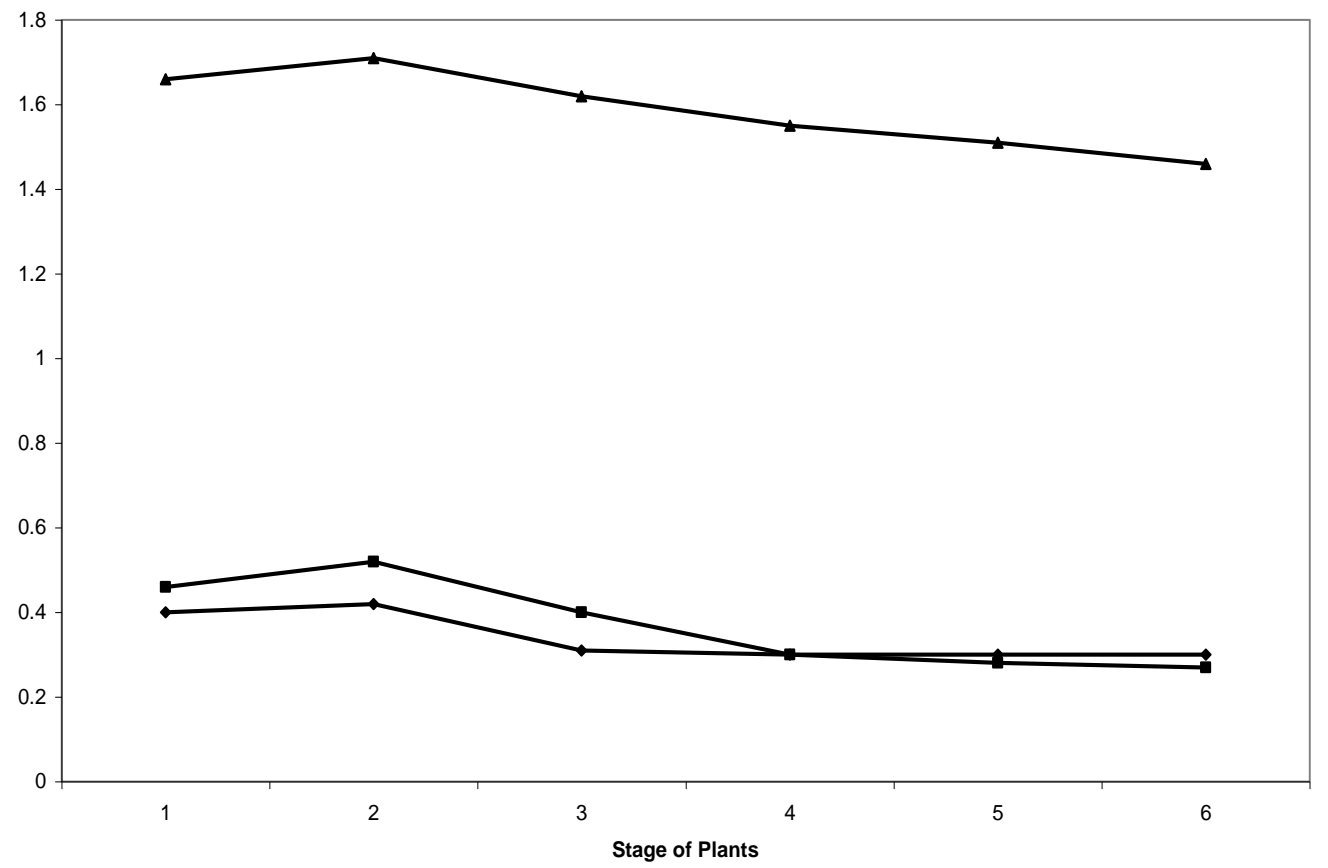

Fig. 3. Density of Handal Plant at Different Growth Stage.\{ (a) Season 2004 / 2005 (b) Season 2005 / 2006. Mi 1/ Emergence 2/ First 2- 4 Leaves 3/ First Flowering 4/ First Fruits Setting and $2^{\text {nd }}$ Flowering 5/ First Seeds Formation and $2^{\text {n }}$ Fruits Setting $6 / 2^{\text {nd }}$ Seeds Formation

maturity stages. In the first season, the plant density at the middle section ranged from 0.60 to 0.72 plants $/ \mathrm{m}^{2}$, while in upper and lower sections no sign of plant growth was observed. That may be attributed to the lack of rain. In the second season, however, plant density of Handal ranged from 0.3 $0.4,0.27-0.46$ and $1.46-1.66$ plants $/ \mathrm{m}^{2}$ for the upper, middle and lower sections, respectively. Mean plant density for the two seasons is shown in Table (5). In the first season, the three wadi sections were significantly different $(P<0.05)$ in their mean plant densities while in the second season, there was not significant difference between the mean plant density of the upper and middle sections. Similarly, there was a significant difference $(P<0.05)$ between the mean plant densities of the lower section in one side and the upper and middle sections on the other side. Earlier, Mohamed (1989) found that the plant densities of this specie in upper and middle sections of wadi Abu Salam were 0.10 and 2.50 plant $/ \mathrm{m}^{2}$, respectively.
Table 5. The Plant Density of Handal as Affected by Different Wadi Sections

\begin{tabular}{|ccc|}
\hline $\begin{array}{c}\text { Section of } \\
\text { Wadi }\end{array}$ & $\begin{array}{c}\text { Season 2004 } \\
\text { /0 5 }\end{array}$ & $\begin{array}{c}\text { Season 2005 } \\
\text { / 06 }\end{array}$ \\
\hline Upper & $0.00 \mathrm{a}$ & $0.34 \mathrm{a}$ \\
Middle & $0.65 \mathrm{~b}$ & $1.37 \mathrm{~b}$ \\
Lower & $0.00 \mathrm{a}$ & $1.55 \mathrm{c}$ \\
\hline
\end{tabular}

Means within the same column having the same letter are not significantly different at $\mathrm{P}=0.05$ according to Duncan's Multiple Range Test.

\section{The rate of photosynthesis}

The rate of photosynthesis measured as net assimilation rate (NAR) during the two seasons is shown in Fig. (4). The rate of photosynthesis increased with time. The maximum rate was reported at the end of the vegetative stage during the 8th week (2.2 and $2.34 \mathrm{gm} . /$ day for the first and second seasons, respectively). The rate of photosynthesis started to decline after wards through 


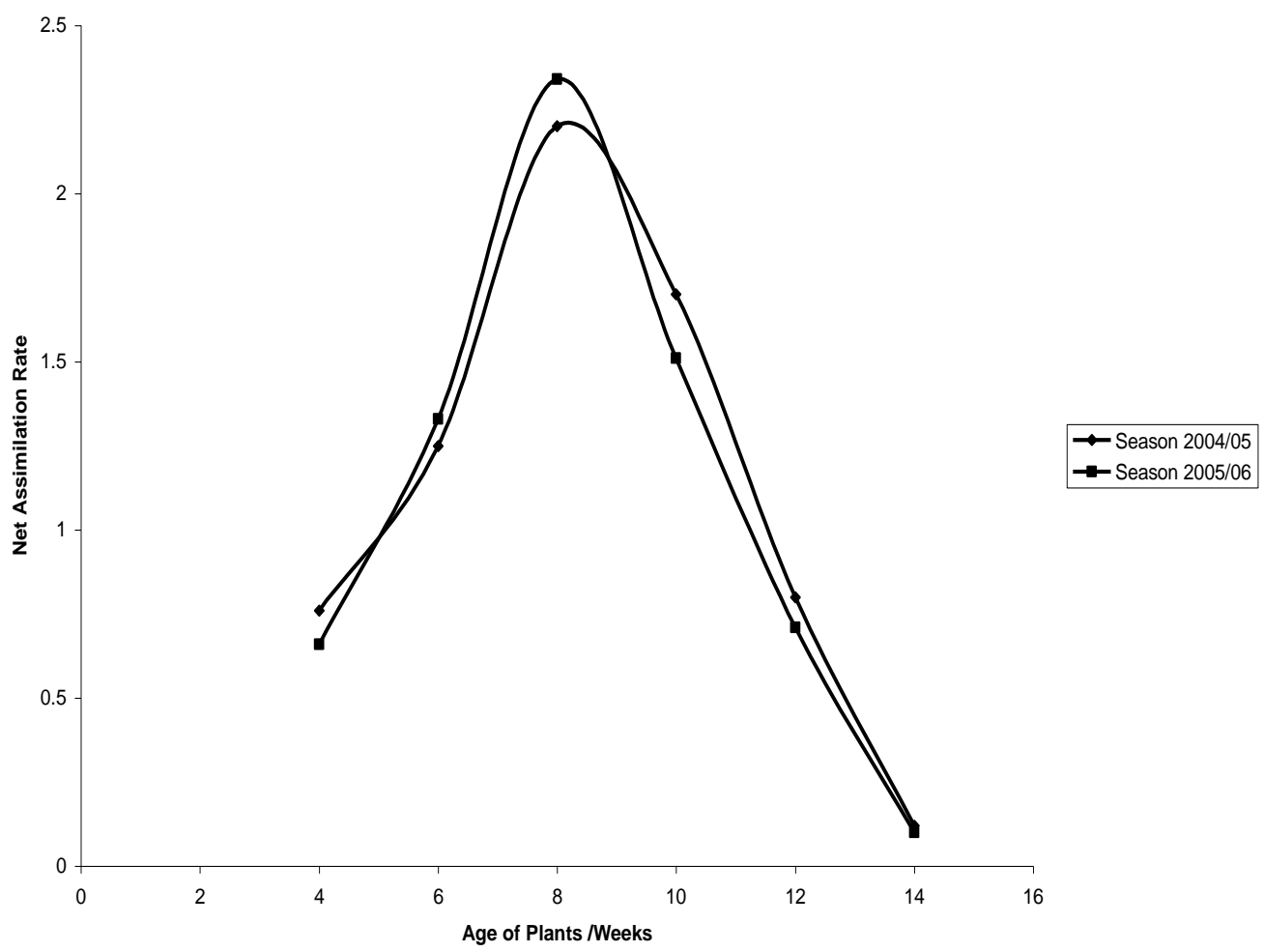

Fig. 4. The Net Assimilation Rate for Handal Plant

flowering stage during the 10th week and continued to do so till reaching the maturity stage at the 14th week of growth. The minimum rate of photosynthesis recorded 0.12 and $0.10 \mathrm{gm}$./day for the first and second seasons, respectively. That could be attributed mainly to plant leaf senescence, fading, dropping and the effect of leaves shading each other. These results agreed with the findings of Hassanin (1993) who concluded that the plant growth is directly related to leaf area which is, in turn, considered as the basic photosynthesis measuring system.

\section{Shoot /root ratio}

The shoot /root ratio of Hundal plant during deferent growth stages is illustrated in Fig. (5). At the beginning of growth, the number of roots was higher than the number of shoots and the shoot /root ratio was 0.4 and 0.39 for the first and second seasons, respectively. That could be attributed to priority of the young plant to develop more roots to meet the needs for absorbing water and nutrients. Afterwards, as the vegetative stage proceeded, the shoot/root ratio started to increase till it reach the maximum ( 0.76 and 0.80 at the first and the second seasons, respectively) at the peek of the vegetative growth stage of the plant during the 8th week. Then, as the plant approaches the maturity stage, the shoot/root ratio decreased gradually till reaching 0.30 and 0.22 at the first and the second season, respectively. That could be explained by leaf senescence and dropping of the old branches. 


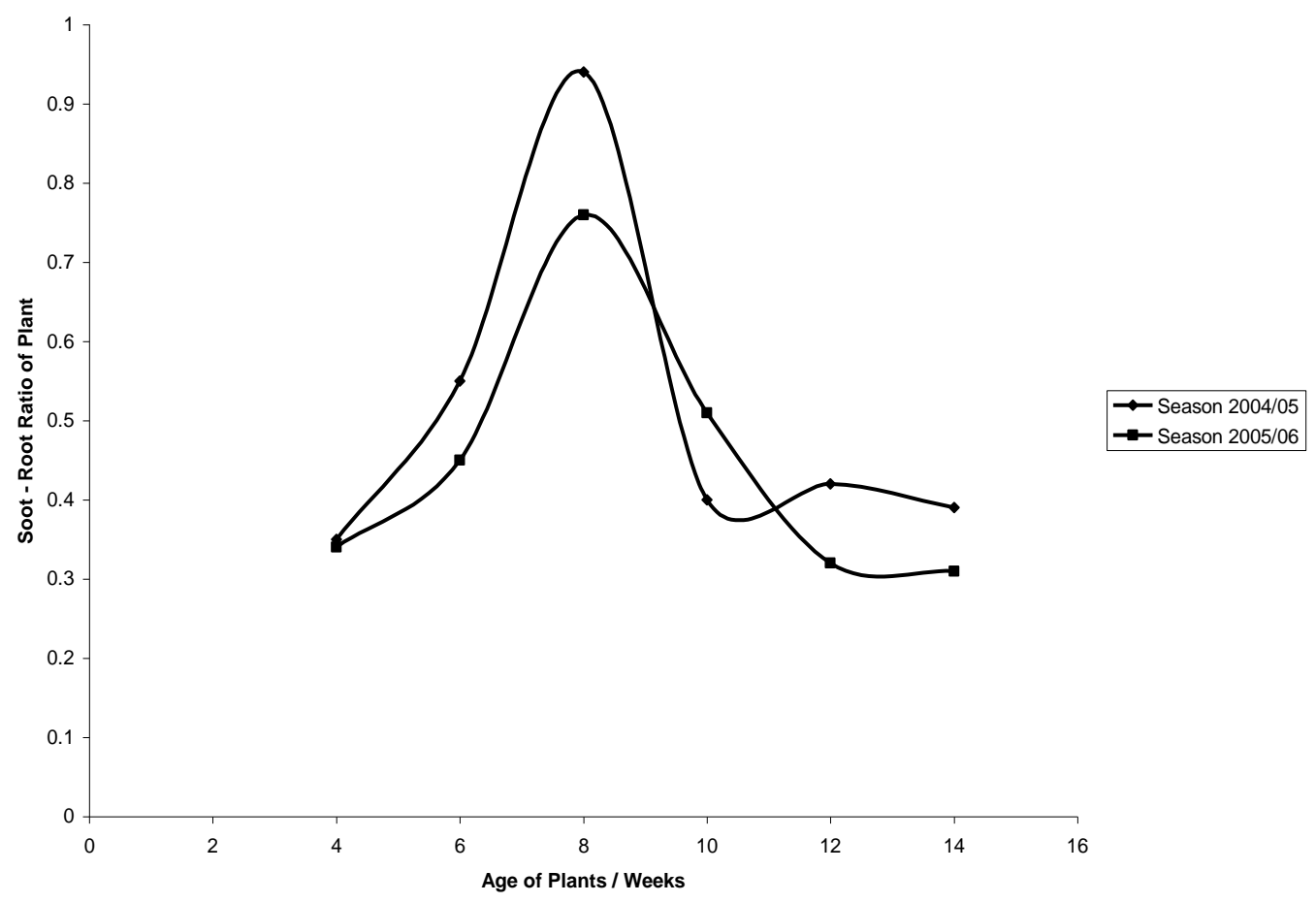

Fig. 5. Shoot/ Root Ratio of Handal Plant

\section{REFERENCES}

A.A.A.D. 1988. Arab League of Nations Medical, Aromatic and Poisonous Plants.

Al/Allah M.O.A. 1997. Studies on Citrullus colocynthis oil seed physico-chemical Properties and Indestrial Application, MSc. thesis, University of Gezira, Oil Seed Processing Research Institute.

AL Awad, ALA.A. 1981. Studies on the Family Cucurbitaceae, MSc. thesis, University of Khartoum, Department of Botany.

Cloudily- Thompson, J.L. 1965. Desert Life. Pergamon Press, Oxford. 86P.

Dalziol 1937. The useful plants of west Tropical Africa Grown Agents of the colonics 4, Milbank, Westminster, London, S.W.I.

EL-Awodat, M.and Laham, George 1992. Medical Plants and their Uses, second edition. EL Ahali for printing, editing and distribution, pp. (69).
EL-Djoy, A. 1996. Agricultural Engineering, Encyclopedia of Medical and Aromatic Plants, Book One. Mudbouli Library, Egypt, pp. 398, 386388.

Hassanin, A.M. 1993. Crop Physiology. pp. 110113.

Mohamed, F.A. 1989. Ecological changes and Production of Wadi Abu Salam, Nile Province. M.Sc Thesis, University of Gezira.

MSTAT-C Program 1991. A software program for the design, management and analysis of agronomic research experiments.

Ryan, J.; Estefan, G. and Rashid, A. 2001. Soil and plant analysis Laboratory manual, $2^{\text {nd }}$ edition. International Center for Agricultural Research, Aleppo, Syria.

Survey Department 2004. Locality map of Wadi Abu Salam (Valley), Ministry of Defense, Khartoum, Sudan, sheet no. 45G.

Watson, D.J. 1952. The physiological basis of variation in yield, Advances in Agronomy, 4:101-14. 